Sultan Qaboos University Journal of Arts \& Social Sciences

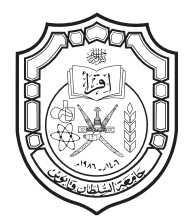

جامعة السلطان قابوس

مجلة الآداب والعلوم الاجتمأعية

\title{
Prospects for Collective Security Cooperation in the Gulf
}

\author{
Hani Albasoos \\ Assistant Professor \\ Department of Political Science \\ College of Economics and Political Science \\ Sultan Qaboos University \\ hani.adam@squ.edu.om
}




\title{
Prospects for Collective Security Cooperation in the Gulf
}

\author{
Hani Albasoos
}

\section{Abstract:}

The process of establishing a new security structure in the Gulf should take into consideration the failures of the past and the political differences among GCC countries which have been impeding collective security in the Gulf. Collective security arrangements should consider the strategic circumstances that currently exist and the numerous security problems which have implications for security beyond the region itself. These include the Iraqi security situation, Iranian foreign policy and its nuclear and missile programmes, the stability of Yemen, borders disputes, and the deepening Sunni-Shia divide with its destabilising political and social effects on the region. Cooperation in the Gulf should not be limited to military aspects, but must also include economic development, counterterrorism, disaster response, environmental, social and cultural issues. Gulf States should institutionalise their security structures which is important for the establishment of a strong joint command needed to achieve collective security and prosperity and effectively leading to development and stability in the region.

Keywords: Collective Security, Cooperation, Joint Command, Political Stability, Gulf Region.

\section{آخاق التعاون الأمني الجماعي في الخليج}

\author{
هاني البسوس
}

الملخص:

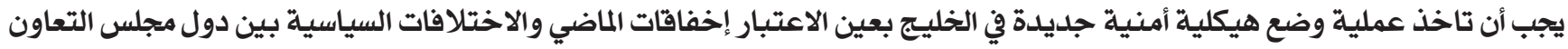

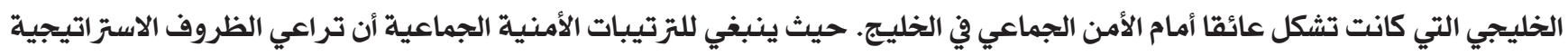

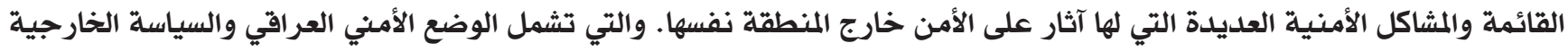

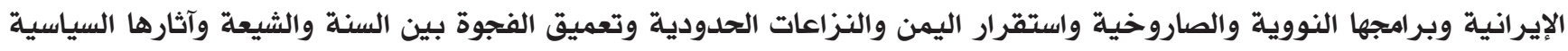

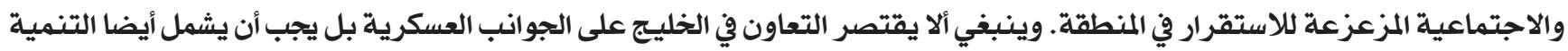

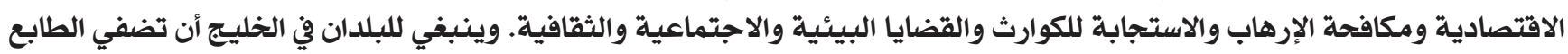

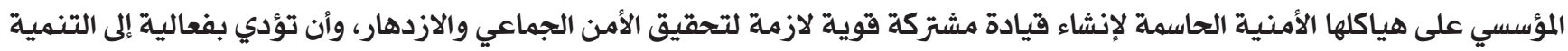




\section{Introduction:}

Security is a broad-spectrum subject, covering issues which can be classified differently according to different scholars. It deals with a wide range of risks whose probabilities we have little knowledge about and of contingencies whose nature we can only dimly perceive. Security does not have a proper framework within w $\rightarrow$-hich to gauge a nation's sense of security. The concept of security does not lend itself to a neat and precise formulation. However, it means freedom from anxiety and apprehension. It also means protection, assurance and freedom pathways to the establishment of a good human value. Security is accepted as a concept in international relations and as a central organising notion by both practitioners and academicians. It leads to a comprehensive perspective no less useful than the one provided by power or peace.

This research intends to understand the reasons for the failure of security structure in the Gulf and to present a framework that addresses the need for a secure and peaceful formation of relationships, provides security for all states in the Gulf, and meets the concerns of the outside powers. References are made to Iran and Saudi Arabia because of their geopolitical situation and their roles as the leading power in the Gulf which have considerable security concerns and are critical to the region's peace and security.

This research will reflect a methodological originality and a hypothetical enquiry of an assignment with empirical and analytical overviews. It is built on a privileged relationship and upon a mutual commitment to common values. It will attempt to analyse the reasons for failure to create a collective security frame. It promotes economic cooperation, political stability and collective security, and efficiently addresses interdependencies between the Gulf States.

\section{Research Problem:}

The Gulf region is a part of the Middle Eastern regional system with its distinctive security issues and political practices. The Gulf region is wealthy of natural resources and has a strategically geopolitical location which makes it of a great importance. It is a strategic geographical place on the international security agenda, giving it an important role in regional affairs. A series of critical events have highlighted this significance including, the dangers posed by the Iran-Iraq War, the Iraqi invasion of Kuwait and the US-led invasion of Iraq, which has led to permanent stationing of US troops in the region. Recently, in the aftermath of the Arab Spring, a sequence of security developments have oc- curred in the Middle East leading to radical political changes, civil war-like conditions, and the fight against terrorism, in addition to the regional tension between Iran and most countries in the Gulf. The political polarisation in the Middle East has led to contradictory policies that overshadow doubt about the Gulf security and stability.

\section{Research Importance:}

The situation in the Gulf requires formulating a concept of regional cooperation to escape the persistent cycle of instability. It is critical to think of different mechanisms to enhance the security situation through establishing regional security cooperation built on respect of autonomy, rights, and borders, and to settle conflicts peacefully, with respect to human rights and liberties, and refraining from intimidation. Cooperation and mutual trust are crucial in the Gulf and should clearly include all States to reflect the hopes of their peoples. Exploring collective security arrangements could begin with dialogue and through seminars and conferences at the regional level. Yet, given that the political and ideological differences in the region, countries in the Gulf need to improve military cooperation and to create $a$ joint command to guarantee stability and to overcome regional challenges.

\section{Contribution:}

The focus on Gulf cooperation is in contrast with the current practices of disagreement and conflict of interests. Therefore, the establishment of security structure remains unanswered. Hence, the institutionalisation of security cooperation would be appropriate for this subregional security system based on an initial network of bilateral relationships to be followed by a formal and multilateral framework. Operationally, the Gulf States should incrementally start from limited cooperation on specific issues to a collective approach, putting all issues on the table intending for an inclusive package deal to achieve interoperability of cooperation in training, logistics, and infrastructure. To develop efficiency, they have to enhance their military capabilities and forge strategic alliances with external actors such as the UK and the USA and to seek the expansion of NATO into the Gulf region, through defence cooperation agreements.

\section{Keywords:}

Collective Security, Cooperation, Joint Command, Political Stability, the Gulf Region. 
Literature Review:

This part is a theoretical foundation to conceptualise and achieve basic understanding of security as an appropriate framework for security in the Gulf region. The concern is the achievement of a comprehensive understanding of the Gulf security. Thus, to understand security, it is necessary to discuss the "collective security" concept, as security is a fundamental prerequisite for economic cooperation and political stability.

\section{Collective Security:}

Security has undergone a major conceptual transformation and individual states are no longer able to solve security issues alone. The future track of international relations will consider how individual states define priorities in order to react to emerging security challenges. Modern security problems require immediate coordinated responses by all actors who have a stake in their outcomes (Andreatta, 1996). "Pressing security issues such as drug trafficking, human trafficking, global warming, food crisis, and energy crisis are some of the issues that require multilateral approaches and instruments. These security issues also require an organization to be more inclusive in type rather than exclusive, in order to maximize the possibilities of cooperation and favourable outcomes" (Sevilla, 2011).

The concept of collective security has no precise vision of what it means or entails. Its basic system of belief is based on cooperation among states, i.e., an act of aggression by one of its members is considered to be an act of aggression against all of its members (Johansen, 1991). An alliance exists to protect its members against an identifiable threat in accordance to article 5 of NATO Charter (NATO, n.d.). Yet, it cannot be identified in advance who might be the attacker, which entails collective security with a certain ambiguity regarding the development of threats to it. Course of action must be instantaneous among members of the collective security alliance. Members must "be willing and able at all times to muster overwhelming strength for collective defence at successive points of conflict...Thus, unless there is a high degree of commitment to the system, it will quickly fall apart" (Clark, 1995).

Collective security entails that the members are definite of their understanding of the nature of aggression, so that they can agree when aggression on one member has occurred. However, in international politics, such clarity has been rare. The idea of collective security differs fundamentally from other security arrangements made by states, though it is not entirely new. "Balance-of-power systems generally have been attempts by the major actors to provide regional solutions to the problems of aggression. In contrast, collective security aspires to an unprecedented degree of universality, by requiring every member of the system to act" (Clark, 1995). The theory is elegant in its simplicity. Yet this may be the root of the problem of achieving collective security, as the simple is often the most difficult to achieve.

The goal of establishing a system of collective security is more to shape a world comprised of states in a principled community. "Collective security has broadened in theory and practice to encompass far more than military remedies to keep the peace. We know that collective security is a potent means to impose tough economic sanctions on defiant regimes. Collective security has increasingly become an essential ally in many humanitarian relief operations. Increasingly, we are fusing peacekeeping and peace enforcement operations. Another dimension of collective security today is statebuilding operations" (Clark, 1995).

Criticism of the concept has revolved around the universality and automaticity of the commitments of collective security. The norm of collective security requires that states will subordinate their "own immediate interests to general or remote ones" (Betts, 1992). States fail to honour commitments to automatic actions, on the pretext of national interest, sovereignty, independence, etc. As Inis Claude notes: in the Gulf War, Iraq's aggression against Kuwait "was the collective security theorist's dream case: the flagrant and lonely aggressor, overwhelmed by a substantially united community" (Claude, 1993).

Collective security allows for a preventive diplomatic function to breaches of the peace. However, the mechanism for military responses is not well developed. "Collective security is likely to delay reaction to attack, because the members of the system must react, mobilize, and coordinate their response ad hoc to counterattack to take back lost territory, rather than on direct defence to defeat aggression" (Betts, Summer 1992). Another concern for collective security is that it might denigrate the value of unilateralism. Unilateralism affords a greater flexibility with the least amount of power. Individual states have the greatest latitude to enhance their security, while multilateralism affords the greatest amount of power, but the least amount of flexibility. Multilateral response may actually turn minor wars into major ones. Generally, small wars confined to a particular region are not of immediate concern to every state, however, every state, regardless of alliance is called on to physically act. Small wars can 
thereby become global ones (Clark, 1995).

The Gulf Region:

The Gulf region has constantly captured the attention of the world. It has been an essential part of the power game between rising and falling empires. In the early decades of colonisation, the Gulf was considered as a bridge between the East and the West. It was used by colonial powers as a strategic point crossing on the way towards their colonies in the East (Binhuwaidin, 2015). The strategic and economic features of the Gulf region have made it of significant value to all the states adjacent its shores. It is crucial to the entire world's economy and political life. This considerable geopolitical situation, in addition to its central position as a global energy source, have made the Gulf an attractive economic and political destination to outside powers, particularly those in the West, despite being amongst the most unstable regions in the world (Sadeghinia, 2011). "The Gulf region is one of the most strategically important regions in the world. The presence of its large oil and gas reserves coupled with some of its most vital water routes to international movement of merchandises would require well-coordinated and transparent policies by which all littoral states including other regional and extra- regional state actors should actively involve" (Sevilla, 2011).

As a region of significant importance, successive colonial forces, throughout history, including the Portuguese, the Dutch, and the Ottomans, have competed to dominate the Gulf region due to its strategic position. "The apatite for Middle East oil and gas led powerful countries, the United States, Europe, Japan, and China to compete with each other over its control" (Sevilla, 2011). Nonetheless, the Gulf has been influenced by the British and lately by the Americans, who have shaped the region. There has been a changing security and political priorities of these two powers. While, "the Soviets had been gaining influence in Iraq ever since the overthrow of the monarchy in 1958 and the Chinese were also fishing for influence by their support of the Popular Front for the Liberation of the Arabian Gulf" (Amirsadeghi, 2011).

British involvement became deeper from the 19th century, particularly when oil supply became more critical. The region became more important because of its vast energy resources, at the time of the British influence. It had been recognised that the Gulf lay in the legitimate sphere of influence of Britain. The latter was looking at three enduring missions; "maintaining interstate order, protecting the free flow of commerce, which later included petroleum; and keeping out other Great Powers
(Macris, 2010)." Lately, the US influence has grown in the region following the British withdrawal, and more recently the changes in the US strategy which involved building up its military presence, especially after Desert Storm and invasion of Iraq. The aforementioned missions had by 1991 been assumed almost entirely by the American leaders. The United States exercised its influence in the two central littoral states of Iran and Saudi Arabia.

\section{Critical Events: Cycle of Instability}

The Gulf States share, particularly, member-states of the Gulf Cooperation Council (GCC), have embraced security arrangements on the regional level. Yet, regional powers, Iran, Iraq and Saudi Arabia have constantly strived to enforce their overarching domination on the Gulf States. The Marxist (communist) philosophy adopted in many parts of the Arab world since the 1930s was an imminent danger to the security of the Gulf region. The final aspiration of many of the regimes with Marxist orientations and their affiliates was to change the status quo by enforcing ruling Marxist machinery as alternatives for existing monarchies in the Gulf. Another major threat emanated from Nasserism, which escalated its intervening impact on the Arab world in the aftermath of the colonial era. "The political doctrine advocated by Nasser's revolutionary regime, in Egypt, aiming to replace the traditional nationstate with a neo-Arab state system, was diametrically opposed to the conservative thought deeply rooted in the Gulf countries" (Binhuwaidin, 2015).

In the early 1980s, there has been an endeavour to export the militant policy of the Iranian revolution to the Gulf States as a model to embrace. The Iranian revolution's simultaneous manipulation of religion and sectarianism threatened to destabilise the social structure of the Gulf countries, as the Iranian Islamic revolutionary model was a potential political alternative for the ruling monarchies in the Gulf States. This could have caused domestic divisions and conflicts based on race and sect in the region. It led to the formation of the GCC originating from the inevitability to balance Iraq and Iran in the 1980s. The superior and more powerful neighbours posed an existential threat to the survival of the ruling families. Later, the regional dangers to the security of the Gulf region emanated from the al-Qaeda terror network, a violent multinational terror organisation struggling to dismantle the conservative regimes of the Gulf. Al-Qaeda operatives and affiliates have infiltrated the region disseminating fanatic thought and distorted Islamic philosophy, disguised 
with political ideology and disruptive agenda.

After the Iraqi invasion of Kuwait in 1990, the United States persuaded KSA they will be next target for Iraqi expansion. Gulf States shifted their priorities against Iraq and the "U.S.-led Coalition victory in the Gulf War helped the United States overcome its disgrace in Vietnam and reinstated its position as the dominant world hegemony" (Sevilla, 2011). Gulf States viewed instability as a strategic instrument which could lead to cooperation against possible threats. "In their confrontations with potential dangers threatening their security, the GCC countries have relentlessly defended their existence using all possible means" (Binhuwaidin, 2015). It is difficult to establish actual peace and security in the Gulf, unless states realise that peace, security and development are necessities in the region. This would lead to coordination and cooperation "made up of interconnected variables wherein one cannot exist without the others. (Sevilla, 2011).

The overthrowing of Saddam Hussein's regime in 2003 has a significant impact on the strategic and security scenery in the Gulf and the wider Middle East region. The consequences of the invasion of Iraq have passed beyond its borders. Yet, despite the changes in the Gulf, states' policies are still driven more by national interests and less by common orientations (Bahgat, 2008). Nonetheless, the Gulf Cooperation Council, not a security community, has made progress toward being so (Yaffe, 2004).

\section{The Arab Uprising:}

The outbreak of popular uprisings against some Arab governments, spearheaded by the Tunisian revolution in 2010, has immense ramifications on the social and political spheres. The uprisings resulted in "unfavourable transformations reinforcing extremist ideologies embracing political Islamic thought, liberal political ideas, and sectarianism" (Binhuwaidin, 2015). The ideologies that leaked into the GCC countries have appeared as new challenges destabilising the conservative sociopolitical structure underpinning the Gulf region. Thus, the major threats to the Gulf security in the post Arab 'Spring' era have penetrated the social structure of the Gulf countries (Binhuwaidin, 2015).

The transformation was substantiated by the mobilisation of young generations across the Middle East region demanding freedom and human rights and giving prominence to democracy-building in their societies. The uprisings have transformed the region, which has been undergoing a period of major political developments and transformation. Though, the political chang- es have been diverse in their causes and outcomes, their impact on the region are varied. Violence has spread in the region motivated by deeply entrenched forces of authoritarian regimes.

The increase of anarchy in the region, where popular uprisings took place, has aggravated political, economic and military elite retaliation in Egypt, Libya, Syria, and Yemen offering perception into the potential approach of the political change. This unexpected turmoil raises the question about the potential fundamental change across the region. However, doubts have accumulated as the uprisings became evident to represent the stalling and obstacles of these regional political changes. Syria is the more dramatic challenge, but other states may have long-term implications. This means there is a fundamental state of affairs that may well lead to an unprompted outbreak of widespread disturbance in the region or can develop gradually into a fundamental social movement. It is difficult to envisage when and how this may occur (Abdo, 2013).

The political transformation in the region has raised significant questions concerning stability, security and the political state of affairs. The waves of protests and uprisings have led to radical changes where a major political earthquake seemed to have hit the region. The internal changes led to transformations at the regional and international levels. The consequences of the uprisings are mixed and thinking of these consequences in terms of a transition to democracy is oversimplifying the results of the events. Whatever the demands of the participants, most uprisings will not lead to democracy in the near future. Violent confrontations have made democratisation unlikely, and weak state institutions, unable to sustain the rule of law, do not promise imminent democratic systems.

\section{Political Polarisation \& Sectarianism:}

Many of the regimes in the Middle East region have maintained some societal balance between ethnic or religious groups. Some of these groups are more easily incited towards regime change, while others have a vested interest in supporting the regime. The transitions, particularly in Tunisia and Egypt, brought new movements and parties vying to alter the existing political structure, which involves shifting identities and changing loyalty patterns. This reflects the preexisting internal cleavages and factions. These hidden divi-sions have become conducive and contagious. Some intellectuals believe that the uprisings have created the conditions for rising sectarianism by undermining the authoritarian regimes that once kept them 
under control. "When states are weak, sectarianism rises" (Aaltola, 2011).

Regional divisions and competition for power, as a longstanding feature of the Middle East politics, have been amplified by the current developments and the growing antagonism between Iran and Saudi Arabia, which have been broiling since the fall of the Ba'ath party in Baghdad in 2003, which weakened the geopolitical role of Iraq. The United States-led coalition which overthrew Saddam Hussein's regime changed the nature of Iran's relationship with Iraq, which had been transformed from deep hostility to cordiality (Klug, 2012). Hence, the hostility between Sunnis and Shiites has emerged causing the region to fall into the sectarian trap. "Though Islam is the only religion engulfing the region, the dormant historical differences between Sunnis and Shi'a are brewing under the surface. The security of the GCC countries came under explicit threat after the eruption of sectarian conflicts in predominantly Islamic countries such as Iraq and Syria" (Binhuwaidin, 2015).

The Saudis have adopted a policy of balancing against Iranian influence in the Arab world. Bahrain, a Shiite majority country governed by Sunni rulers, may increasingly be seen as Berlin in the Cold War where the two camps play out their rivalries (an assumption may not be accepted by other scholars). The grievances of Bahrain's majority Shiite population have given a sectarian basis around which Iran has framed its concerns. This rising tension between Sunni and Shiite communities was augmented by Saudis helping to crush protests led by the Shiite majority in Bahrain (Abdo, 2013). In contrast, Iran has maintained great support to its ally in Syria, President Bashar al-Assad, whose rule is built around his Shiite-rooted Alawite minority (Lyon, 14 February 2013.). The decision of the Arab League to impose sanctions on Syria for violently suppressing internal opponents and protesters was supported by the League except for two Arab member states against the sanctions, apart from Syria itself, which were the Shiiteled Iraqi government and the government of Lebanon, dominated by the Shiite group Hizbullah (Klug, 2012). In fact, the uprising in Syria is a continuation of changes taking place elsewhere. Protesters of various backgrounds came together in opposition to a repressive government. However, Iran has maintained an account (Klug, 2012) of distinguishing the opposition to the rule of al-Assad from protests elsewhere. Accordingly, while Tunisia, Egypt, Libya, and Yemen reflect a nation's resistance to tyranny and a growing popular religious consciousness, the oppression of demonstra- tors in Syria is, in Iran's story, a consequence of foreign plot rather than legitimate national grievances. While Iranian media reports have generally welcomed the Arab uprisings in the region, they describe the instability and conflict in Syria as a conspiracy by the United States and certain Western countries taking revenge on Syria for its position of supporting the Palestinian and Lebanese Islamic resistance movements against Israel. The truth is that the fall of al-Assad regime is the most significant geostrategic setback to Iran, depriving it of a strong regional partner. Thus, Iran is likely to continue standing with the Syrian ruler, supporting reforms instead of changing the regime.

The growing politicisation of Shia doctrine as a threat to regional government survival is sustained by Iran's assertive foreign policy attitude after the United States' military interventions in Iraq and Afghanistan. Balzan believes that Iran is responsible for fomenting instability in the GCC countries since the Iranian Revolution of 1979. She said: "Iranian clerics sought to export their version of political Islam throughout the Muslim world and targeted socioeconomic cleavages in the smaller and militarily weaker Gulf countries in order to undermine social cohesiveness, religious unity, and above all, the states' Islamic legitimacy" (Balzán, 2014). This makes the presence of Shia opposition groups a susceptible internal security matter for the GCC.

\section{Policy Analysis:}

The concept of Gulf security has become the centre of attention in the early seventies after the Gulf countries had gained their independence. "Encountering the interval perils threatening their security, the Gulf countries espoused comparable protective policies" (Binhuwaidin, 2015). To maintain stability, security, and free movements of oil and other commodities, it is necessary to strengthen the security of the Gulf. The rising threats and challenges to regional political-military stability have become of primary concern. Thus, security and social stability prospects are pressing towards military cooperation (Kechichian, 1985). The Gulf Cooperation Council, established in 1981, is seen as an integral part of the security structure in the Gulf region. It was assembled to respond to existential threats coming from internal violence and regional power to the Gulf countries. Small states did not have a choice because their survival in such a tentative and unsteady situation characterised by conflict and disorder could simply be diluted by any of the regional powers. The GCC countries have cooperated in the economic, political, and security realms. "However, this level of coopera- 
tion has left much to be desired. The ambitious goals set out in its charter have proven to be too difficult and ambitious to address" (Balzán, 2014).

\section{Achieving Regional Cooperation:}

A heavy security burden permeates most aspects of life in the Gulf, which began with a series of critical events, particularly the Iraqi invasion of Kuwait in 1990. The regional strategic changes resulting from the increase of terrorism, regional power shifts, and fluctuations in the global economy have put forward the notion of regional collective security (Al-Qahtani, Spring 2014). In fact, the continuation of security threats has influenced states to uphold their military strength at the present level now and in the foreseeable future with no prospect of reducing the current volume of defence expenditure in the near future. However, the power differences between countries in the Gulf have resulted in a deep-seated asymmetry in their security requirements. Consequently, different threat perceptions have existed within the societies despite the effect of the regional security paradigm on all states.

Striking asymmetry in the states security requirements will continue to exist due to the disparity between the security resources and the security needs of each entity. There is an imbalance of power between countries in the Gulf which permeates to different aspects of their lives (Oktav, 2011), particularly military capabilities. Any efficient security arrangement will need to take into consideration the differences of regional history and tendencies in the distribution of power, both in the Gulf and between regional states and external powers (Sadeghinia, 2012). In addition, configuration of security policies requires an essential distinction between the power and responsibility of the Gulf States and their connected to the political and economic legitimacy in each country. The GCC was established to respond to internal security needs of the six member states. "Currently, the GCC is faced with security problems, including territorial issues of Iraq and Iran, U.S. invasions, demographic trends, and structural imbalances of policies" (Ulrichsen, 2009).

Currently, the Gulf States are faced with many challenges, particularly when it comes to finding common ground and harmonised policies that go in line with the their vision of a "common destiny" (Balzán, 2014). Cooperation challenges derive from the structural struggle inherent in the region lack of a 'supranational' authority makes it unfeasible for a Supreme Council, such as the GCC, to enforce its decisions. "Efforts to further integrate are usually hampered by some of the mem- bers' opposition, as in the case of Oman's firm rejection of Saudi Arabia's call for a Gulf Union in 2013. In a more recent development, the spat that led Saudi Arabia, the UAE, and Bahrain to cut diplomatic relations from Qatar exhibits an ominous sign for the future of the GCC. This unprecedented move in the history of the GCC highlights the disharmony and deep-rooted tensions in the organisation" (Balzán, 2014).

The security structural of the Gulf region is susceptible to both internally and externally driven threats. States fear outside interference and domestic strife and revolutions. "The most imminent threats will come from within the GCC states' domestic setting" (Balzán, 2014). The internal source of insecurity is coupled with the unpredictable course of political developments in the Middle East.

Threat perceptions are different for each of the Gulf States. This has resulted in frequent foreign policies clashes despite being part of the same coalition, the GCC. There is no common understanding of what threats the rulers consider most imminent to the survival of their regimes. Lack of a "strategic consensus on who the GCC should guard against (Legrenzi, 2011, p. 78). has constantly resulted in contradictory approaches and prioritisations of security concerns and agendas. Lack of agreement on the strategic situation translates into different security decision-making modalities at the regional level. "Threat perceptions in the GCC flow from two different sources: those that emanate from within and are characterised by political dissent and sectarianism, and external threats posed by outside powers with superior military capabilities and the capacity to galvanise subversive elements in the domestic affairs of the GCC states" (Balzán, 2014). In general, the complexity of threats defies accurate prediction and assessment even if information is not limited. The complexity even increases as measures are taken to encounter threats. Considering a threat as a national security issue depends on what type of threat it is, how the recipient state perceives it, and the intensity of the threat. The intensity of the threat depends on its specificity, nearness, probability, the weight of its consequences and whether or not perceptions of threat are amplified by historical circumstances (Buzan, 1991, pp. 23-25). A society may stereotype the other as constituting a collective threat. The Gulf region is politically fragmented and sectarianism is a crucial element in weakening societies. Thus each is perceived to be the cause of a sense of vulnerability. The security perspective emanating from one country's perception has been rejected by another. Yet, the 
removal of the physical threat will enable a change in focus on the security of individuals and the achievement of their basic human rights. As such, the focus will shift away from the macro level of state analysis to that of the micro of the family and the individual.

Security Structural Design

The ongoing differences in the Gulf region, the instability in Iraq, the war against terrorism, the war in Syria, and the conflict in Yemen have led to changes in the security circumstances in the regional military stability. However, the Gulf States have failed to entirely develop a regional security structure to cope with these changes. Given the threats faced by the region, it is necessary to establish an organisation to cooperate in the fields of security and defence. "In spite of numerous attempts to cooperate and coordinate security policies, GCC states' intentions expressed in declarations and yearly communiqués have largely remained at the rhetorical level" (Balzán, 2014). This is caused by lack of a supranational authority that can enforce decisions, challenges driven by either unresolved border disputes or fear of hegemony, and reliance on outside security guarantors, such as the United States (Alsayed, 2013). Faced with extreme challenges of insecurity and threats, the Gulf States should increase cooperation and assemble an institutional instrument for collective security. The Internal Security Cooperation raises the question of sovereignty among members, especially for the smaller states. The fear of Saudi and Iranian dominance might influence the region, and thus keeps the smaller monarchies in a state of permanent doubt and absolute distrust. Consequently, "the GCC has sought to establish a unified military command for decades without yielding any results reflects the ambivalence felt by some member-states" (Legrenzi, 2011). Nonetheless, the smaller states could successfully benefit from a strong, integrated defence mechanism.

Prompt initiatives are crucial for collective security in the Gulf to overcome external challenges and to crack down on extremist ideologies penetrating the region and endangering its stability. However, any attempt to influence the traditional and conservative values intertwined in the social fabric of the region will certainly result in the fall of the socio-political formation underlying the Gulf States. The latter must negotiate potential threats in the aftermath of the 'Arab Spring' and should not underestimate the contingency of other dangers traditionally jeopardizing the security of the region (Binhuwaidin, 2015).

Iraq is a possible player in any emerging regional security arrangements with a minimal influential function.
Progress in Iraq is likely to be influenced by the cooperation between other regional powers. However, the growing sectarian conflict will continue to threaten the region and foreign interests. Hence, the United States and other global actors should work towards containing sectarian division in Iraq and throughout the Gulf region (Bahgat, 2008). The recent Nuclear Deal between Iran and the $(P 5+1)$, led by the U.S., would enhance the prospects for regional stability upon coordination with Saudi Arabia and other States in the region. "Ideology remains an important determinant of the Iranian and Saudi foreign policies, but, contrary to much professional speculation, these policies are and will continue to be driven less by ideological orientations and more by realist national interests" (Bahgat, 2008).

The strategic relationship between Arab Gulf States and the United States and other outside states must develop to deal with military threats and other threats, "including ideological extremists, non-state actors and their state sponsors, and a growing range of forces designed to fight asymmetric wars" (Hunter, 2010). The United States must agree on the best means to encourage long-term security and stability in the region, and must continue to play a major role as a regional power that can with the Gulf States set criteria and requirements for a new regional security structure. The emerging dynamic in the Gulf States has begun to diversify their political, economic, and security partnerships with ascending powers other than the United States, such as China, Russia, and India. The choice of security partner is becoming more difficult by increased domestic and regional insecurity deriving partly from Yemen, Iraq, and Iran. "Each country has pursued a blind policy of serving either the interests of oneself or allies (in the case of the US). While others, like the small littoral Arab states (UAE, Qatar, Bahrain, Yemen) and Saudi Arabia, have all accepted short-sighted belief that the Gulf security could only be sustained with the presence of the US forces to counter balance the potential threats that may come from regional powers such as Iran and Iraq" (Gresh, 2015).

\section{Joint Military Command:}

The Gulf States have depended on outside powers to provide their military security. "Maintaining the security of the Gulf requires not only cooperation among regional actors but also firm political commitments by outsiders who share common interests on the region's security" (Sevilla, 2011). In fact, all GCC members have bilateral security agreements with the U.S., and they generally grant priority to these arrangements over 
multilateral ones. "For decades the nations of the Arabian Gulf have relied on foreign security guarantors with strategic national interests to preserve the collective security of the region" (Al-Qahtani, Spring 2014). Each member's defence forces enjoy outstanding partnerships with the U.S. and regularly participate in joint military exercises under U.S. command to advance shared interests in Gulf security and to increase cooperation among armed forces. The diminutive outcomes in the cooperation of external security have improved military cooperation even through limited steps. Security cooperation should include necessary military deployment through an organisational mechanism to strengthen GCC collaboration. This is to strengthen their military capabilities in a consistent and efficient approach by "making their forces interoperable, they will achieve the potential of defending the region against any threat" (Cordesman, 2013). In fact, the Gulf States have achieved superiority in military equipment and high-tech defence systems (Balzán, 2014), but this cannot alone provide security.

The Peninsula Shield Force (PSF), established in 1986, was invented basically by the GCC to be the building block for a potential collective defence mechanism to achieve self-reliance as a goal (Legrenzi, 2011). "The creation of the PSF represented a positive step toward increased stability for a region whose security is critical to the global economy. Moreover, it demonstrated willingness on the part of GCC nations to decrease dependence on foreign security guarantors and increase autonomy over Gulf affairs" (Al-Qahtani, Spring 2014). Military development in the Gulf would play broad roles in both internal and external security, namely a regional powerhouse (Thompson, 2009). Yet, the inability to either discourage or efficiently respond to the Iraqi invasion of Kuwait in 1990, demonstrated the failure of the PSF as a security arrangement, leading to proposals for its disbandment in 2006. PSF improvement has been marked by a number of challenges over the years, but frequent developments in the strategic security environment imply that the time is right for the PSF to develop into a more autonomous regional security organisation (Al-Qahtani, Spring 2014). Failure of the PSF to protect Kuwait led Sultan Qaboos of Oman in 1991 to propose the development of a largestanding army of 100,000 troops in the GCC. Though, "Oman was not wholly successful in achieving its objective during the main negotiation period up to 1995 , it did manage to contribute to small shifts in GCC security policy during periods of conflict" (Mason, 2014). Thus, the 2001 formation of "Belt of Cooperation", a joint air defence command and control system, and 2004 agreement on "intelligence sharing" have made slight progress, and "they have helped lay the ground work for further cooperation" (Cordesman, 2013).

These attempts strengthen cooperation; however, the slow pace at which they progress towards full cooperation, coupled with conflicting interests among the Gulf States will definitely impede them from achieving full military integration. In 2009 an agreement to create a joint force for rapid intervention was ratified to address security threats, as demonstrated in the UAESaudi intervention in Bahrain in 2011. Thus, it took the Arab uprisings in 2011 to achieve a fundamental reorientation of the GCC security policy which favoured higher numbers of PSF troops. Following the uprisings and the growing disturbances in the region, the Gulf States have adopted an increasingly proactive regional stance. The emphasis is on greater cooperation among the Gulf States. Thus, the GCC secretariat at the end of the 34th Summit in Kuwait in 2013 announced the establishment of the Gulf Academy for Strategic and Security Studies in the United Arab Emirates. The academy will strengthen military cooperation through a unified educational system. "The academy will look to increase knowledge transfer and greater comprehend a unified realisation of threats across the entire GCC region. There will be an initial focus on missile defence, border security and counter terrorism" (Mustafa, 11 Dec. 2013).

A missile defence system in the Gulf requires a "consideration of command and control options, sensors and shooter placement, as well as numerous policy considerations such as engagement criteria, inventory, and interoperability" (Al-Qahtani, Spring 2014). It represents a strong near-term proposal for collective security development since it facilitates a high level of essential cohesion and coordination for more complex military functions. In an important development at the 35th GCC Summit in Doha in 2014, member-states agreed to establish a unified armed forces command. The joint military command is based in Riyadh, Saudi Arabia, with strategic geographic depth larger than the rest of the GCC countries. This is due to the fact that Saudi Arabia has the biggest economy and armed forces as well as a population greater than that of the other five member-states combined.

Despite the complexities obstructing defence integration, the incorporation of a joined defence system is considered as a necessity (Legrenzi, 2011). Yet, the smaller states are reluctant to place their armed forces under a unified command that could be dominated by 
regional powers such as Saudi Arabia, which makes it difficult to have an integrated command in this context. However, it is possible that when Gulf States face serious external threats, their disagreements are sidelined in order to endorse an advanced joint front. "Indeed, internal and external challenges recently prompted the six Arab monarchies of Saudi Arabia, the United Arab Emirates, Qatar, Kuwait, Oman and Bahrain to announce the formation of a joint military command. However, the past experience indicates, this initiative might remain hostage to intra-Gulf Cooperation Council rivalries and make only a marginal contribution to Gulf security" (Guzansky, 2014).

\section{Conclusion:}

Establishing a system of collective security is necessary to characterise a world that is more of states in a principled community. The geographical authenticity of the Gulf community has strengthened mutual social and tribal ties among its peoples. The amalgamation between the geographical and social configuration, especially in the GCC states, has an impact on their economy and security, which increase in construction of regional security architecture.

The Gulf security is dependent upon the ability of the Gulf States to eradicate potential threats that jeopardise the survival of the values entrenched in the region. The security policy of the Gulf should consider the internal and external risks threatening the political, economic, and social structure of the states in the Gulf. The enforcement of containment policies to prevent threats in the region is a shared mission by all the Gulf States because the security and stability of the Gulf concern every country in the region. It is more useful for the Gulf regimes to reinforce the internal frontier merging the past relations between the followers of different religious sects in their own countries through the implementation of their common values and shared interests where all people, regardless of differences in ethnicity or sect have the same rights and responsibilities. By doing this, containment policy will eradicate external dangers of interference in the region and will establish a joint collective security through the improvement of military capabilities and increasing mutual arrangement to endorse the development of a defence system.

A long-term security in the Gulf should include an obligation on the part of the United States to carry out a broad political approach to broker confidence-building measures with Iran. Security measures should be based on a balance of military power between the three main players in the region, Iran, Iraq and Saudi Arabia. These countries with strong demographic bases and armies could disturb the peace and security of the region. It is imperative to include Yemen in any arrangement because it is a major state in the neighbourhood, and is a stronghold of extremism. In fact, the measures should incorporate the interests of all regional states, with minimal foreign military presence in order to eliminate external domination in the long-term in the region. Such collective security arrangements should go in parallel with wider economic reforms and constructing a regional economic interdependency.

\section{References:}

Aaltola, T. B. \&. M., 2011. The Arab Uprising: Causes, Prospects and Implications. The Finnish Institute of International Affairs, FIIA Briefing Paper 76, March.

Abdo, G., 2013. The New Sectarianism: The Arab Uprisings and the Rebirth of the Shi'a-Sunni Divide. The Saban Centre for Middle East Policy, Brookings, April, Issue 29.

Al-Qahtani, M., Spring 2014. The Case for a Gulf Cooperation Council Peninsula Shield Force. Journal of International Affairs, XVII(1).

Alsayed, W., 2013. The Future of Gulf Defence Cooperation, s.l.: Retrieved from http://www.iiss.org/en/ manama\%20voices/blogsections/2013-e202/futuregcc-cooperation-0989.

Amirsadeghi, H., 2011. The Security of the Persian Gulf. London: Routledge.

Andreatta, F., 1996. Collective security: theory and practice of an institution for peace in the XX century. London: London School of Economics and Political Science (University of London).

Bahgat, G., 2008. Security in the Persian Gulf: Perils and Opportunities. Contemporary Security Policy, 29(2).

Balzán, C., 2014. Security Cooperation in the GCC: Challenges and Opportunities. s.I.:Florida International University.

Betts, R. K., 1992. Systems for Peace or Causes of War? Collective Security, Arms Control, and the New Europe. International Security. 
Binhuwaidin, M. M., 2015. Essential Threats to the Security of the GCC Countries in the Post Arab Spring Era. DOMES: Digest of Middle East Studies, 24(1).

Binhuwaidin, M. M., 2015. Essential Threats to the Security of the GCC Countries in the Post Arab Spring Era. DOMES: Digest of Middle East Studies, 24(1).

Buzan, B., 1991. People, States and Fear: An Agenda for International Security Studies in the Post-Cold War Era. London: Longman.

Buzan, B., 1991. People, States and Fear: An Agenda for International Security Studies in the Post-Cold War Era. London: Longman.

Clark, M. T., 1995. The trouble with collective security. Orbis, $39(2)$.

Claude, I. L., 1993. The Gulf War and Prospects for World Order by Collective Security . In: R. F. H. I. a. R. H. Dorff, ed. The Persian Gulf Crisis: Power in the PostCold War World . s.I.:Westport, Conn.: Praeger.

Cordesman, A., 2013. Securing the Gulf: Key Threats and Options for Enhanced Cooperation , s.I.: CenCentre for Strategic and International Studies. Retrieved from https://csis.org/files/publication/130219_Securing_the_Gulf.pdf .

Gresh, G. F., 2015. Gulf Security and the U.S. Military: Regime Survival and the Politics of Basing. California: Stanford Security Studies.

Guzansky, Y., 2014. A Joint Army for the Arabian Gulf. RUSI Journal: Royal United Services Institute for Defence Studies, 159(6).

Hunter, R. E., 2010. Building Security in the Persian Gulf. Santa Monica, CA: Rand Corporation.

Johansen, R. C., 1991. Lessons for collective security. World Policy Journal, 8(3).

Kechichian, J. A., 1985. The Gulf Cooperation Council: search for security. Third World Quarterly, , 7(4).

Klug, T., 2012. Have the Arab Uprisings Lost Their Spring?. The Palestine-Israel Journal www.pij.org , 18(1).
Legrenzi, M., 2011. The GCC and the International Relations of the Gulf Diplomacy, Security and Economic Coordination in a Changing Middle East. London: I.B. Tauris.

Lyon, A., 14 February 2013.. Analysis: Arabs mired in messy transitions two years after heady uprisings. Reuters, 12 Feb.

Macris, J. R., 2010. The Politics and Security of the Gulf: Anglo-American Hegemony and the Shaping of a Region. London : Routledge.

Mason, R., 2014. The Omani Pursuit of a Large Peninsula Shield Force: A Case Study of a Small State's Search for Security. British Journal of Middle Eastern Studies, 41(4).

Mustafa, A., 11 Dec. 2013. GCC Announces a Joint Military Command, s.l.: Defense News, http://defence.pk/ threads/gcc-unified-military-command-I-updates-discussions.290929/.

NATO, n.d. s.I.: http://www.nato.int/cps/en/natohq/ topics_110496.htm.

Oktav, Ö. Z., 2011. The Gulf States and Iran: A Turkish Perspective. Middle East Policy, 18(2).

Sadeghinia, M., 2012. Security Arrangements in the Persian Gulf. Digest of Middle East Studies, 21(1).

Sadeghinia, M. F., 2011. Security Arrangements in the Persian Gulf : With Special Reference to Iran's Foreign Policy, Durham Middle East Studies Series. Reading : Perseus Books, LLC. .

Sevilla, A. H. \&. J., 2011. Re-constructing the Political Mindset of the Persian Gulf Security Vol. 3 No. 1, 2011, pages 49 - 67. International Journal of West Asian Studies, 3(1).

Thompson, E. V., 2009. The Iraqi Military Re-enters the Gulf Security Dynamic. Middle East Policy, 16(3).

Ulrichsen, K. C., 2009. Internal and External Security in the Arab Gulf States. Middle East Policy, 16(2).

Yaffe, M. D., 2004. The Gulf and a New Middle East Security System. Middle East Policy, 11(3). 